MISES: Revista Interdisciplinar de Filosofia, Direito e Economia ISSN 2318-0811

Volume IV, Número 1 (Edição 7) Janeiro-Junho 2016: 161-181

\title{
Ludwig von Mises e as Organizações Libertárias: Lições Estratégicas*
}

\author{
Jörg Guido Hülsmann ${ }^{* *}$
}

\begin{abstract}
Resumo: O autor apresenta a história do envolvimento de Ludwig von Mises em organizações em prol da liberdade, desde a defesa do livre comércio nos anos 1920 até sua participação na fundação da Sociedade Mont Pèlerin em 1947. Dessa maneira, o autor ilustra o papel central desempenhado por Mises no desenvolvimento do pensamento liberal/libertário no século XX.
\end{abstract}

Palavras-Chave: Ludwig von Mises. Liberalismo. Libertarianismo. Organizações libertárias.

\section{Ludwig von Mises and Libertarian Organisations: Strategic Lessons}

\begin{abstract}
The author presents the history of Ludwig von Mises's participation in organizations devoted to liberty, since his defense of free trade in the 1920's until his participation in the foundation of Mont Pèlerin Society in 1947. Hence, the author illustrates the central role played by Mises in the development of the liberal/libertarian thought in the 20th century.
\end{abstract}

Keywords: Ludwig von Mises. Liberalism. Libertarianism. Libertarian organizations.

Classificação JEL: B31, B53.

\footnotetext{
* Publicado originalmente em: New Perspectives on Political Economy. Vol. 8, Issue 1 (2012): 19-40.

Traduzido do inglês para o português por Claudio A. Téllez-Zepeda.

** Jörg Guido Hülsmann é senior fellow no Mises Institute e autor de Mises: The Last Knight of Liberalism e de The Ethics of Money Production. Leciona na França, na faculdade de Direito, Economia e Gestão da Université d'Angers. E-mail: jgh@guidohulsmann.com
} 


\section{I - INTRODUÇÃO}

Ludwig von Mises (1881-1973) se envolveu, em três diferentes momentos da vida, em organizações libertárias: na década de 1920, foi membro de várias organizações defensoras do livre comércio; em 1938, foi um participante proeminente do colóquio organizado por Walter Lippmann (1889-1974) em Paris; e, depois da Segunda Guerra Mundial, colaborou com a Foundation for Economic Education (FEE) de Leonard Read (1898-1983), com a Libertarian Press de Frederick Nymeyer (1897-1981), e se tornou membro fundador da Mont Pèlerin Society. Para posicionar sua interação com essas organizações em contexto histórico, começaremos por considerar brevemente como a produção acadêmica libertária era organizada no século XIX. Passaremos, então, à defesa de Ludwig von Mises no século XX, primeiro caracterizando suas contribuições gerais à produção libertária e depois discutindo seu envolvimento nas organizações mencionadas. Concluiremos destacando a continuidade histórica entre Mises e os defensores do laissez-faire no século XIX.

\section{II - OrganizaçÃo da PRODUÇão ACADÊMICA LIBERTÁRIA NO SÉCULO XIX}

A história política da civilização ocidental é, em grande medida, a história da batalha entre os defensores do poder do governo - os intelectuais de corte - e os defensores da liberdade ${ }^{1}$. Para a maior parte da história ocidental, as linhas de frente nesta batalha não têm nenhuma relação com a economia. A defesa da liberdade foi feita em termos da providên-

1 ACTON, Lord. The History of Freedom. Grand Rapids: Acton Institute, 1993; ROTHBARD, Murray. An Austrian Perspective on the History of Economic Thought. Auburn: Ludwig von Mises Institute, 2006. 2v. cia divina que ordena a ética e a justiça para o homem. No século XVI, então, a convicção de que havia critérios teológicos inabaláveis para a arbitragem de conflitos políticos desmoronou sob o impacto das insurreições protestantes. Daí em diante, o debate se tornou cada vez mais secularizado e situado em termos da prudência natural. Um produto intelectual dessa abordagem foi a nova ciência da Economia Política, que surgiu no século XVIII e ofereceu o suporte científico para o liberalismo político.

O liberalismo clássico, no apogeu, caracterizou-se por um grande número de economistas inovadores que continuaram e ampliaram os escritos dos fisiocratas franceses, de Adam Smith (1723-1790) e de David Ricardo (1772-1823). Os escritos inspiraram um movimento internacional liberal clássico liderado por homens como Richard Cobden (18041865) e John Bright (1811-1889) na Inglaterra, Frédéric Bastiat (1801-1850) na França e John Prince-Smith (1809-1874) na Alemanha. Por volta da década de 1860, esse movimento varreu os Estados Unidos e todos os países da Europa Ocidental, incluindo a Alemanha. O ponto central de suas percepções era que as condições materiais da humanidade somente poderiam ser melhoradas pela produção e pela da troca, e qualquer coisa que estivesse no caminho da produção e do intercâmbio era suscetível de ser abolida sem prejuízo para a sociedade. Assim, o governo só era justificável à medida que prestasse os serviços que as associações livres de particulares não podiam prestar. De acordo com Adam Smith e muitos outros, ele precisava proporcionar serviços policiais e militares, estradas, pontes e vias marítimas, bem como todo um pacote do que mais tarde seria chamado de bens públicos. De acordo com a escola francesa dos industrialistas no início do século XIX - Charles Comte (1782-1837), Charles Dunoyer (1786-1862) e outros -, o único papel do governo seria fornecer serviços de segurança. Esperavam que esse papel diminuísse constantemente como consequência do aumento da cultura huma- 
na; o futuro utópico da civilização ocidental seria uma sociedade sem governo. Os pensadores mais radicais dentre os liberais clássicos não viam razão alguma para justificar a existência do governo. A seus olhos, a produção de segurança poderia ser confiada a empresas privadas, assim como todos os demais ramos da produção. Nas famosas palavras de Gustave de Molinari (1819-1912): “Ou isso é lógico e verdadeiro, ou os princípios sobre os quais a ciência econômica está baseada são inválidos"².

Em suma, a agenda liberal clássica visava a uma redução mais ou menos dramática do papel do governo e, por volta da na década de 1850, essa agenda se tornou explícita. Os pensadores mais corajosos - homens como Gustave de Molinari, Herbert Spencer (1820-1903), Max Stirner (1806-1856) e Paul Émile de Puydt (1810-1891) - chegaram a conquistar o respeito pelo empreendimento intelectual de pensar a respeito de uma sociedade sem Estado ${ }^{3}$.

Os economistas do liberalismo clássico foram, em grande parte, impedidos de entrar nas instituições públicas tradicionais de ensino superior, que cultivavam o raciocínio nos moldes antigos a respeito das questões políticas sob o controle do governo. Isso não era uma grande desvantagem naqueles dias, porque, de qualquer maneira, havia poucos economistas empregados publicamente. A competição das teorias econômicas e das propostas de políticas ocorreu em um mercado verdadeiramente livre para ideias. Seus pro-

\footnotetext{
${ }^{2}$ MOLINARI, Gustave de. The Production of Securyti. Trad. J. McCulloch. New York: Centre for Libertarian Studies, 1977. p. 3. [Em língua portuguesa a obra está disponível na seguinte edição: MOLINARI, Gustave de. Da Produção de Segurança. Pref. Murray N. Rothbard; Trad. Erick Vasconcelos. São Paulo: Instituto Ludwig von Mises Brasil, 2014. p. 21. (N. E.)]

${ }^{3}$ Ver: MOLINARI, Gustave de. "De la production dela sécurité". Journal des Économistes, Volume XXV, (Février 1849): 277-90; DE PUYDT, Paul Émile. "Panarchic". Revue Trimestrielle (Juliette 1860): 22245; SPENCER, Herbert. Social Statics. New York: Schalkenbach Foundation, 1995 [1850]; STIRNER, Max. Der Einzige un sein Eigentum. Stuttgart: Reclam, 1991 [1844].
}

tagonistas eram homens ricos independentes; não tinham de se curvar diante dos poderes existentes. Para difundir sua nova ciência, construíram uma série de instituições de pequena escala que variava desde redes soltas de contatos literários e pessoais, passando por periódicos e revistas acadêmicas até campanhas políticas mais ou menos organizadas e associações de livre comércio ${ }^{4}$.

O livre mercado de ideias foi decisivo para a vitória arrebatadora que os liberais clássicos alcançaram em meados do século XIX. Por volta dos anos 1860, o establishment político e intelectual de todos os países ocidentais percebeu o avanço liberal como uma ameaça mortal à sua posição, e com razão. Os governos do Ancien Régime [Antigo Regime] haviam estabelecido uma resposta estratégica baseada em dois pilares: por um lado, surgiu uma coalizão antiliberal entre o establishment conservador e o nascente movimento socialista ${ }^{5}$; por outro lado, a criação de um mercado para economistas profissionais com o objetivo de controlar o mercado de ideias. Os governos começaram a criar um grande número de cátedras de Economia Política em suas universidades e a preencher a maioria desses novos cargos com estadistas convincentes. Especularam que a autoridade venerável das universidades superaria a autoridade dos pioneiros

4 Por exemplo, o jornal Censeur Européen, dos anos 1820 e 1830, gerenciado por Charles Dunoyer, Charles Comte e Augustin Thierry (1795-1856); a Anti-Corn Law League [Liga Contra as Leis de Cereais], fundada em 1838 por Richard Cobden e John Bright; o jornal Libre Échange, fundado por Frédéric Bastiat, em 1844; e o Kongress Deutscher Volkswirte [Congresso dos Economistas Alemães] fundado em 1863, do qual dentre os membros se destacam os nomes de John Prince-Smith, Wilhelm Adolf Lette (1799-1868), Franz Hermann Schulze-Delitzsch (1808-1883), Heinrich Bernhard Oppenheim (1819-1880), Julius Faucher (1820-1878), Karl Braun (1822-1893), Max Wirth (18221900), Viktor Böhmert (1829-1918) e Theodor Barth (1849-1909).

${ }^{5}$ A respeito do importante caso alemão, que forneceu o modelo para estratégias semelhantes em outros países, ver: RAICO, Ralph. Die Partei der Freiheit. Stuttgart: Lucius \& Lucius, 1999. 
da nova ciência. Isto se mostrou correto. $\mathrm{O}$ próprio significado da ciência econômica sua natureza e importância, bem como suas implicações políticas - veio a ser redefinido sob o impacto de um processo de contratação estabelecido pelo governo em grande escala.

Começaram a surgir escolas inteiras de Economia, cujo caráter "nacional" foi determinado pelos que controlavam as nomeações. A estratégia foi aplicada primeiramente na Alemanha, onde as autoridades aplicaram a Escola Historicista Alemã de Economia, sob o rígido controle de Gustav Schmoller (18381917), no lugar da ciência econômica em praticamente todas as universidades do Reich ${ }^{6}$. E de lá se difundiu para outros países. $\mathrm{Na}$ França, as autoridades da Terceira República "instalaram uma escola rival em cadeiras universitárias recém-criadas e altamente prestigiadas por toda a França, profissionalizando os economistas franceses e despojando a Escola Liberal, principalmente não-acadêmica, de sua autoridade intelectual sem paralelos" Nos Estados Unidos, a American Economic Association (AEA) [Associação Econômica Americana], fundada em 1885 por economistas treinados na Alemanha, também seguiu o caminho do schmollerismo ${ }^{8}$. Na Rússia, as au-

${ }^{6}$ Idem. Ibidem.

${ }^{7}$ Ver: SALERNO, Joseph. "The Neglect of Bastiat's School By English-Speaking Economists: The Puzzle Resolved". Journal des Économistes et des Études Humaines, Volume 11, Numbers. 2 \& 3 (June / September 2011): 451-95.

${ }^{8}$ Sobre o caso dos Estados Unidos, ver SALERNO. "The Neglect of Bastiat's School By English-Speaking Economists". Op. cit. Entre os economistas norteamericanos mais proeminentes que receberam sua educação de pós-graduação na Alemanha, figuram William Graham Sumner (1840-1910), Frank William Taussig (1859-1940), Frank A. Fetter (1863-1949), Richard Theodore Ely (1854-1943), Edwin Robert Anderson Seligman (1861-1939) e John Bates Clark (1847-1938). A respeito do papel da American Economic Association (AEA), que foi estabelecida em 1885 segundo o modelo da Verein für Socialpolitik de Schmoller, ver os comentários em: HOFSTADTER, Richard. Social Darwinism in American Thought: 1860-1915. Philadelphia: University of Pennsylvania toridades aparentemente sentiam que o schmollerismo era muito brando e começaram a contratar professores marxistas para suas cadeiras de Economia Política, cavando assim o túmulo do regime czarista9.

Alguns anos antes, um ataque mais sutil, porém igualmente terrível contra o liberalismo clássico foi lançado na Grã-Bretanha. O ímpeto inicial veio de John Stuart Mill (18061873), que, sob a influência de Harriet Taylor (1807-1858), sua esposa socialista, começou a praticar a arte mortífera do comprometimento intelectual ${ }^{10}$. Tornou intelectualmente palatável usar a palavra "liberalismo" para designar programas políticos do mais puro tipo social-democrata. O ápice do absurdo dessa onda dos millianos foi alcançado em 1934, quando o economista da University of Chicago, Hen-

Press, 1944. Esp. p. 147; REZNECK, Samuel. "An American Depression, 1882-1886". American Historical Review (January 1956), p. 294.

9 Ludwig von Mises observou: "Com seu ódio ao liberalismo e à democracia, o próprio czarismo, através da promoção do marxismo, preparou o caminho para a ideologia bolchevista". MISES, Ludwig von. "Anti-Marxism". A Critique of Interventionism. New York: Arlington House 1977. p. 120.

10 Esta redefinição ficou praticamente ignorada até que Ludwig von Mises retomou o argumento liberal clássico no final da década de 1920. Mises chamou Mill de "o grande defensor do socialismo. Todos os argumentos que podem ser colocados em favor do socialismo foram por ele elaborados com afetuosa atenção. Em comparação a Mill, todos os outros autores socialistas, mesmo Karl Marx (1818-1883), Friedrich Engels (1820-1895) e Ferdinand Lassalle (1825-1864), muito dificilmente mostram alguma importância". (MISES, Ludwig von. Liberalism: In the Classical Tradition. Trad. Ralph Raico. Irvington-onHudson: Foundation for Economic Education, 1985. p. 195). [Utilizamos a passagem em português da seguinte edição brasileira: MISES, Ludwig von. Liberalismo: Segundo a Tradição Clássica. Preâmbulo de Louis M. Spadaro; Prefs. Thomas Woods \& Bettina Bien Greaves; trad. Haydn Coutinho Pimenta. São Paulo: Instituto Ludwig von Mises Brasil, 2ª Ed., 2010. p. 204]. John Maynard Keynes (1883-1946) concorda com essa ideia ao afirmar que: "Desde a época de John Stuart Mill os economistas de autoridade têm estado em forte posição de reação contra todas essas ideias [individualismo e laissez faire]". KEYNES, J. M. The End of Laissez Faire. London: Hogarth Press, 1926. p. 25ss. 
ry Calvert Simons (1899-1946), fez circular um manuscrito com o título promissor de $\mathrm{A} \mathrm{Po-}$ sitive Program for Laissez-Faire [Um programa positivo para o laissez-faire], no qual pediu a nacionalização de empresas que não poderiam suportar a concorrência do mercado.

A redefinição da Economia Política pelo poder dos números absolutos e da tributação, juntamente com a redefinição autoritária de Mill do liberalismo clássico, combinaram-se em um poderoso golpe que inverteu completamente os ideais e a agenda política. Enquanto na era do liberalismo clássico o objetivo tácito da reforma política fora a redução do poder do governo, agora era o oposto. $\mathrm{O}$ novo ideal não era mais uma sociedade que se emanciparia da intervenção governamental, mas um governo abrangente que governaria uma sociedade socialista projetada por ele mesmo. Sobraram alguns liberais clássicos, homens como Gustave de Molinari, Vilfredo Pareto (1848-1923), Julius Wolf (1862-1937), Ludwig Pohle (1869-1926) e Edwin Cannan (1861-1935). No entanto, lutaram de maneira reativa contra uma multidão esmagadora de intelectuais contratados pelo governo e que adoravam o empregador. O novo ideal socialista-estatista varreu as mentes e monopolizou a imaginação da nova geração emergente. Ao final da Primeira Guerra Mundial, o movimento do liberalismo clássico estava quase morto.

\section{III - O SIGNIFICADO INTELECTUAL DO LIBERTARIANISMO MISESIANO}

Nessa altura, surgiu Ludwig von Mises e, dentro de três anos gloriosos, criou uma reação monumental contra a estatolatria. Entrou em cena com o artigo Die Wirtschaftsrechnung im sozialistischen Gemeinwesen [O cálculo econômico em uma comunidade socialista], de 1920. A argumentação simples e elegante foi devastadora. Afinal, o argumento em prol do socialismo tinha por base uma suposta produtividade maior. Mas como poderia ser mais produtivo do que o capitalismo se o conselho de planejamento socialista não disporia dos próprios termos com os quais poderia indicar as alternativas de investimento? Dois anos mais tarde, em 1922, Mises publicou Die Gemeinwirtschaft: Untersuchungen über den Sozialismus $^{11}$ [A economia coletiva: estudos sobre o socialismo], um verdadeiro tratado sobre todos os aspectos relevantes do socialismo. Trabalhou na tese da impossibilidade do cálculo socialista, demoliu a ideia de que havia algo tal como uma tendência inelutável para o socialismo, criticou a defesa moral do socialismo e, em seguida, elucidou muito bem que verdadeira natureza do socialismo era a destruição de vidas individuais e de instituições sociais. No final do livro, nada restou do ideal formidável do Estado socialista. Conforme afirmou, posteriormente, o historiador e jornalista William Henry Chamberlin (18971969), um admirador do economista austríaco, Mises provou ser uma versão moderna de São Jorge, brandindo sua lança contra um dragão aparentemente invencível ${ }^{12}$. Em 1922, o monstro estava morto; o ideal inquestionável da comunidade socialista tinha sido demolido para sempre.

Entretanto, Ludwig von Mises fez mais do que isso. Cinco anos depois, no livro Liberalismus [Liberalismo] de 1927, defendeu uma versão radicalizada do liberalismo clássico, que sob sua pena fez ressuscitar como uma fê-

\footnotetext{
${ }^{11}$ Traduzido para o inglês em 1936, o livro se encontra disponível atualmente nesse idioma na seguinte edição: MISES, Ludwig von. Socialism: An Economic and Sociological Analysis. Pref. F. A. Hayek; trad. J. Kahane. Indianapolis: Liberty Fund, 1992. (N. E.)

${ }_{12}$ Carta de William Henry Chamberlain para Mrs. Chamberlin, datada de 5-6 de julho de 1949. William Henry Chamberlain Papers. Providence College, Providence, Rhode Island. Citado por: NASH, George $\mathrm{H}$. The Conservative Intellectual Movement in America. New York: Basic Books, 1976. Nash cita Chamberlin como tendo tido que Mises era "um verdadeiro São Jorge combatendo o dragão do coletivismo" (p. 13).
} 
nix a partir das cinzas. Dois anos mais tarde, em 1929, Mises fechou seu sistema de análise social, na já citada obra Kritik des Interventionismus: Untersuchungen zur Wirtschaftspolitik und Wirtschaftsideologie der Gegenwart [Crítica ao intervencionismo: estudo sobre a política econômica e a ideologia atuais], ao lidar com os argumentos em prol da "terceira via" cujas variantes atormentam a civilização ocidental até os dias atuais, mais recentemente sob a forma do blairismo. Nesses trabalhos, Mises não somente defendeu descaradamente os princípios centrais da Escola de Manchester, que até então tinham caído em descrédito geral, mas até os superou. Mostrou que qualquer sistema de terceira via seria inerentemente instável porque não poderia resolver os problemas que pretendia resolver e, assim, motivaria intervenção governamental cada vez maior, até que o sistema intervencionista se transformaria em socialismo absoluto. Mas o socialismo não era viável. Restava apenas um item significativo no cardápio político: $100 \%$ de capitalismo.

Repetidas vezes, Mises insistiu que não havia escolha envolvida nesse assunto. Era ridículo especular sobre alguma política particular de terceira via que se encaixasse nas sensibilidades de uma determinada sociedade. A sociedade era viável apenas à medida que os direitos de propriedade privada fossem respeitados, e pronto.

\section{IV - O envolvimento de Mises nos MOVIMENTOS EUROPEUS EM PROL DO LIVRE COMÉRCIO}

Durante a década de 1920 e início dos anos 1930, Mises foi o representante da Câmara de Comércio Austríaca nas reuniões internacionais e, em particular, nas convenções da International Chamber of Commerce (ICC) [Câmara de Comércio Internacional]. Esta experiência provou ser satisfatória e o pôs em contato com uma rede de estrangeiros com interesses semelhantes. Finalmente, consentiu em uma participação de curta duração em certas organizações europeias dedicadas à promoção do livre comércio.

Ficara muito relutante em se envolver em qualquer campanha política organizada. Em uma carta de novembro de 1924, recusou um cargo executivo honorário em uma associação austríaca de livre comércio, afirmando que, por questão de princípio, não queria aderir a qualquer organização política ou político-econômica ${ }^{13}$. Esta atitude mudou no transcurso de 1925, quando assistiu e desfrutou do seu primeiro congresso da ICC, em Bruxelas, como representante oficial austríaco. No outono do mesmo ano, participou de uma conferência da International Free Trade Organisation [Organização Internacional de Livre Comércio] em Viena e, novamente, aproveitou os discursos ali proferidos ${ }^{14}$. Devido a essas experiências positivas, por fim, acabou por se envolver mais formalmente com outros europeus partidários do livre comércio.

Naqueles dias, o Atlântico era ainda um obstáculo grande demais para uma cooperação mais estreita entre europeus e norte-americanos. Entretanto, não era o único obstáculo. Mises e vários de seus correspondentes sentiram certa hipocrisia por parte de determinados participantes norte-americanos das reuniões do ICC e de outras instituições. Antes de partir para o seu primeiro congresso da ICC em junho de 1925, na cidade de

13 "Aus Grundsatz gehöre ich keiner politischen oder wirtschaftspolitischen Organisation an". Carta de Mises para Freihan-delsbund gegen Teuerung und Wirtschaftszwang", datada de 11 de novembro de 1924. Mises Archive (Moscou, Rússia), 80:60.

14 "Vor einigen Wochen hatten wir in eine von der internationalen Freihandelsorganisation unter dem Namen, 'Mitteleuropäische Wirtschaftstagung' einberufene Konferenz, an der erfreulicherweise mehrere Engländer (z.B. F. W. Hirst, Wedgewood Benn u.a.) teilgenommen haben. Die reden, die auf dieser Tagung gehalten wurden, waren außerordentlich gut [...]". Carta de Mises para Lionel Robbins, datada de 9 de outubro de 1925. Mises Archive, 83:61. 
Bruxelas, na Bélgica, Mises compartilhou essas apreensões com Eric Voegelin (19011985), que residia nos Estados Unidos como bolsista da Rockefeller Foundation. Mises escreveu que esperava encontrar muitos homens do exterior, mas não sabia "que tipo" de norte-americanos que encontraria ${ }^{15}$. O tempo confirmaria tal julgamento e não o dissiparia. Em 1927, depois de participar da Conferência Econômica Mundial da Liga das Nações em Genebra, na Suíça, no mês de maio, e da reunião do ICC em Estocolmo, na Suécia, em julho, escreveu a seu amigo Fritz George Steiner em Paris:

Desta vez, o congresso não foi tão interessante como o de Bruxelas. As conversações transcorreram visivelmente sob a fadiga e a exaustão que permaneceram após a Conferência Econômica Mundial. Os norte-americanos perderam muito do entusiasmo pelo livre comércio europeu dado que temiam que o movimento de livre comércio pudesse se espalhar para os Estados Uni$\operatorname{dos}^{16}$.

Steiner não ficou surpreso, respondendo que também poderia relatar inúmeras anedotas sobre o tema "os norte-americanos em casa

15 "Ich reise nächste Woche nach Brüssel, wo ich beim Handelskammerkongreß mit sehr vielen Amerikanern - ich weiß allerdings nicht welcher Sorte - zusammentreffen werde [...]". Carta de Mises para Eric Voegelin, datada de 12 de junho de 1925. Mises Archive, 79:11.

16 "Der Kongreß was diesmal nicht so interessant wie der in Brüssel. Die Verhandlungen standen sichtlich unter dem Eindruck der Ermüdung und Abspannung, die die Weltwirtschaftskonferenz hinterlassen hat. Die Amerikaner haben viel von ihrem Elan für europäischen Freihandel eingebüßt, seit sie fürchten, daß die Freihandelsbewegung auch nach den Vereinigten Staaten übergreifen könnte". Carta de Mises para Fritz G. Steiner, datada de 11 de julho de 1927. Mises Archive, 62:30. Fritz Georg Steiner foi o autor das obras Die Entwicklung des Mobilbankwesens in Oesterreich (Viena: Konegen, 1913), Die Banken und der Wiederaufbau der Volkswirtschaft (Vienna: Manz, 1920) e Geldmarkt und Wirtschaftskrise (Vienna: Manz, 1925). Durante a Segunda Guerra Mundial, mudou-se para Nova York e ficou em contato com Mises até o início da década de 1960. e no exterior" ou "recomendando água e bebendo vinho"17.

No entanto, Mises envolveu-se mais formalmente com as organizações de livre comércio. Em maio de 1927, ingressou na comissão de imprensa da Europäische Wirtschafts-Union (EWU) [União Econômica Europeia], de Christian Günther (1886-1966), com sede em Haia, na Holanda ${ }^{18}$. Günther liderou o comitê holandês de uma organização europeia de livre comércio chamada Europäischer Zoll-Verein (EZV) [Associação Alfandegaria Europeia]. Durante os próximos dois anos, outros comitês nacionais seriam criados e, por volta de 1929, o EZV contava com muitos políticos e acadêmicos proeminentes entre seus membros, tais como Aristide Briand (1862-1932), Paul Mantoux (1877-1956), Gustav Stresemann (1878-1929), Franz Oppenheimer (18641943) e Norman Angell (1872-1967). Dado o forte envolvimento de alguns desses homens na política partidária, não era de surpreender que o EZV tenha se orientado para objetivos bastante moderados, tais como a harmonização das tarifas dentro da Europa. No início de 1928, no entanto, essa ineficácia mal era visível. Assim, quando o Comitê Internacional do EZV pediu a Mises para que se juntasse às fileiras e também para a criação de um comitê austríaco, ele aceitou. Não levou muito mais do que um ano para que ficasse completamente desencantado com a decisão.

As pessoas do EZV queriam que Mises fosse o presidente do comitê austríaco, mas ele propôs outro homem para o cargo, alguém que conhecia tanto por negócios na Câmara quanto de modo particular, por muitos anos. O dr. Ernst Geiringer (1892-1978) era um executivo da Oelindustrie-Gesellschaft em Viena e casado com Trude Geiringer (1890-1981),

\footnotetext{
17 "Über das Thema 'Die Amerikaner bei sich und im Ausland' oder 'Wasser predigen und Wein trinken' wüßte ich Bände zu erzählen". Carta de Steiner para Mises, datada de 18 de julho de 1927. Mises Archive, 62:19.

${ }^{18}$ Carta de Mises para Europäische Wirtschafts-Union, datada de 19 de maio de 1927. Mises Archive, 86:3.
} 
que Mises conhecera na Primeira Guerra Mundial $^{19}$. Por volta de 1928, os dois homens encontraram um secretário adequado, dr. Robert Breza, também da Câmara. Voltaram-se, então, para a arrecadação de fundos e, por fim, ganharam o apoio de influentes empresários da Alemanha e da Áustria em setembro daquele ano ${ }^{20}$.

Nesse ponto, Ludwig von Mises deve ter tido uma imagem um pouco mais clara da mentalidade dos novos associados internacionais. Vira o nepotismo e a dedicação a outras metas puramente pessoais se desenvolverem à custa da causa da liberdade. Em julho, retirou-se do comitê de imprensa do EWU quando Christian Günther se desassociou do EZV. Mises explicou sua decisão afirmando que temia a proliferação de organizações de livre comércio ${ }^{21}$. Na verdade, em um congresso europeu sobre livre comércio realizado em Praga no início de outubro de 1928, havia menos de dezessete associações presentes ${ }^{22}$. É possível que, nesse momento, Mises já não tivesse mais vontade de investir seu tempo desfilando em um circo de egomaníacos e apenas

19 Sobre a afiliação de Geiringer à Oelindustrie, ver: Mises Archive, 89:12. Trude Geiringer escreveu posteriormente que mesmo que tivesse conhecido Mises primeiro, teria sentido como se tivesse "tirado proveito da guerra", dado que a amizade começou na Primeira Guerra Mundial. O marido também nutria grande respeito por Ludwig von Mises e gostava de chamá-lo de sábio. Posteriormente, os Geiringer foram para New Rochelle, no estado de Nova York, e frequentemente se encontravam com Mises e com os Schüller. Ver a correspondência em: Grove City Archive, Geiringer File. Será que Hilda von Mises (1893-1973), a esposa de Richard von Mises (1883-1953), irmão de Ludwig, que era uma Geiringer tinha relações com esta família?

${ }^{20}$ Ver as cartas de Mises para Ernö Bleier, datadas de 10 de setembro de 1928 e 22 de setembro de 1928. Mises Archive, 87:15, 23.

${ }^{21}$ Também sugeriu que seu nome fora inaceitavelmente associado, via EWU, a certas organizações e pessoas, tais como o parlamentar austríaco social-democrata Emmy Freundlich (1878-1948). Ver: Carta de Mises a Günther, datada de 7 de julho de 1928. Mises Archive, 87:18.

${ }^{22}$ Ver a lista em: Mises Archive, 87:18. esperou por uma oportunidade conveniente para se despedir.

A oportunidade surgiu depois de alguns meses, quando membros do Comitê Internacional e membros da comissão francesa fizeram campanha contra a adesão da Áustria ao Reich alemão (a questão Anschluß). Em carta para Ernö Bleier (1897-1969), Mises exortou o Comitê Internacional a recuar publicamente dessa posição, a menos que a EZV não pudesse encontrar apoio na Áustria ${ }^{23}$. O que isso significava, em particular, que nem ele, nem seus associados austríacos, podiam se dar ao luxo de se associarem a qualquer um dos lados dessa disputa altamente partidária - eles eram, afinal, executivos de organizações semigovernamentais ${ }^{24}$. Quando a EUV não se retirou da campanha, Mises e Geiringer deixaram a organização em fevereiro de 1929.

Esse foi o fim do interlúdio de Mises com o movimento organizado de livre comércio. Daí, passou a se concentrar mais na batalha das ideias.

\section{V - Mises E OS NEOLIBERAis}

O desacordo a respeito da questão do cálculo socialista era apenas sintoma de uma dissidência maior entre Ludwig von Mises e os antigos companheiros de armas.

Não somente Mises defendia descaradamente os princípios centrais da Escola de Manchester, que até então caíra em descrédito geral, mas foi além. Mostrou que qualquer sistema de terceira via seria inerentemente

${ }^{23}$ Ver a carta de Mises para Ernö Bleier, datada de 14 de dezembro de 1928. Mises Archive, 87:57.

${ }^{24}$ Geiringer escreveu que, para ele, seria impossível conciliar qualquer forma de oposição contra um possível Anschluß ("mit meinen Stellungen in den verschiedenen hiesigen Organisationen und Verbänden"). Carta de Geiringer para Bleier, datada de 22 de fevereiro de 1929. Mises Archive, 89:7. Mises fez uma declaração similar. Ver: Mises Archive, 89:4. 
instável porque não poderia resolver os problemas que pretendia resolver e, assim, motivaria intervenção governamental cada vez maior até que o sistema intervencionista se transformasse em socialismo absoluto. No entanto, o socialismo não era viável. Restava apenas uma opção significativa: $100 \%$ de capitalismo. Novamente, Mises insistiu que não havia escolha nessa questão. Era ridículo especular sobre alguma política particular de terceira via que se encaixaria nas sensibilidades de um determinado grupo. A sociedade só era viável uma vez que os direitos de propriedade privada fossem respeitados e pronto.

Essa mensagem ecoou bem nos antigos liberais, que ficaram maravilhados com essa esplêndida reformulação dos ideais de juventude. Os pontos de vista de Mises, todavia, foram recebidos com menos entusiasmo pela geração emergente, que havia sido criada em um ambiente intelectual embebido pelo estatismo. Os professores nas escolas e faculdades chegaram a endossar todas as ideias principais subjacentes ao argumento em favor do socialismo: a doutrina do conflito e da luta de classes, a noção do empobrecimento das classes trabalhadoras sob o capitalismo e a crença de que um sistema capitalista descontrolado tendia para o monopólio.

No lado positivo, Mises definitivamente destronou o socialismo como ideal da política. As energias de F. A. Hayek (1899-1992), Fritz Machlup (1902-1983), Gottfried Haberler (1900-1995), Lionel Robbins (1898-1984), François Perroux (1903-1987) e Wilhelm Röpke (1899-1966) - homens que desempenhariam um papel significativo na formulação das políticas após a Segunda Guerra Mundial no mundo ocidental - não serviam mais ao ídolo do governo onipotente. Isso se mostrou de importância decisiva para o curso da história. Entretanto, a influência de Mises se mostrou demasiado fraca para inspirar neles a coragem necessária para um retorno sincero ao tipo de liberalismo vibrante que caracterizou a Escola de Manchester e o movimento mundial de laissez-faire do século XIX.
Mises ainda não havia publicado o tratado sistemático sobre Ciência Econômica que teria esclarecido o argumento científico para um capitalismo sem restrições. Apresentara alguns elementos importantes de sua teoria econômica geral dos sistemas sociais, mas antes de 1940 ainda não estava claro como esses elementos se interrelacionavam e sobre qual estrutura analítica geral se baseavam. Em 1940, Mises finalmente publicou um tratado geral sob o título de Nationalökonomie: Theorie des Handelns und Wirtschaftens [Economia: teoria da ação e da atividade econômica]. Nessa época, Hayek tinha 41 anos de idade e era um acadêmico bem estabelecido; para ele e para o restante de sua geração, o livro chegou tarde demais - para Röpke, Machlup, Robbins e todos os outros, Mises os afastara do socialismo nos anos 1920. Na mente desses homens, os primeiros trabalhos de Mises sobre a impossibilidade do socialismo e a ineficácia do intervencionismo criaram um paradoxo. Mises os convencera de que o socialismo pleno não era viável nem desejável; também foram persuadidos de que os sistemas da terceira via tinham sido superestimados. Muitos deles, no entanto, ainda não questionavam a afirmação de que o liberalismo do século XIX falhara porque seu programa econômico, o capitalismo de laissez-faire, não proporcionara os bens. Acreditavam ser uma simples questão factual o livre-mercado tender ao monopólio e que as classes trabalhadoras do século XIX haviam vivido na miséria por causa do capitalismo laissez-faire ${ }^{25}$.

Para esses homens, a teoria refutara a viabilidade do socialismo, e a história provara os defeitos do capitalismo. O que era necessário era uma terceira via - uma terceira via que poderia, de alguma forma, contornar a demonstração de Mises de que o intervencionismo era necessariamente contraproducente.

${ }^{25}$ Uma revisão do desempenho histórico do capitalismo do século XIX posto em série após a Segunda Guerra Mundial. O débil início se encontra em: HAYEK, F. A. (Ed.). Capitalism and the Historians. Chicago: University of Chicago Press, 1954. 
A solução que surgiu na década de 1930 teve por base uma construção intelectual que dividiu a economia social em dois elementos: 1) um marco institucional; e 2) os processos que se desenvolveram dentro desse arcabouço, principalmente os processos de precificação. Segundo esse novo credo, o governo não deveria se intrometer nos processos, mas sim estabelecer e manter a estrutura institucional. Tal conjunto de suposições é característico do que veio a se chamar neoliberalismo.

Encontramos uma expressão clara da cosmovisão neoliberal em um artigo que F. A. Hayek escreveu em 1935. Comentando a teoria do intervencionismo de Mises, Hayek observa que não decorre do argumento misesiano que "a única forma de capitalismo que pode ser racionalmente defendida é a do laissez-faire pleno no sentido antigo". Prosseguiu:

O reconhecimento do princípio da propriedade privada não significa necessariamente que a delimitação particular dos conteúdos desse direito, tal como determinado pelas leis existentes, seja a mais apropriada. A questão de saber qual é o arcabouço permanente mais apropriado para assegurar o funcionamento mais suave e eficiente da concorrência é da maior importância e devemos admitir que foi tristemente negligenciada pelos economistas ${ }^{26}$.

As raízes da ideologia neoliberal remontam pelo menos as décadas de 1880 e 1890, quando economistas alemães da Escola Historicista Alemã de Economia e seus discípulos norte-americanos se convenceram de que a concentração industrial tem efeitos nocivos e exigiram moderação via intervenção governamental. Uma das consequências visíveis dessa mentalidade foi a Lei Sherman, que até hoje substitui o poder dos consumidores pelo dos burocratas. Na Alemanha, a filosofia da terceira via tornou-se penetrante na Sozialpo-

26 HAYEK, F. A. "The Nature and History of the Problem". In: HAYEK, F. A. Individualism and Economic Order. Chicago: University of Chicago Press, 1948. p. 135. litik instigada sob o Kaiser Wilhelm II (18591941). A França seguiu, invocando a necessidade de uma terceira solução, como fizeram os Estados Unidos sob o New Deal.

Ainda assim, as primeiras declarações programáticas do neoliberalismo foram publicadas apenas na década de 1930 - novamente, sem surpresa, na Alemanha e nos Estados Unidos. A declaração mais influente veio de um economista de Chicago, o supracitado Henry Calvert Simons, que, em 1934, distribuiu o já mencionado documento de trabalho com o título "The Nature and History of the Problem" [Um programa positivo para o laissez-faire] - em que a palavra "positivo" indicou que esse programa justificava uma ampla intervenção governamental, ao passo que o laissez-faire clássico era um programa "negativo", visto que não proporcionava tal justificação. Simons apelou ao governo para regular a moeda e os bancos, impedir a formação de monopólios e proporcionar uma renda mínima para os desamparados - uma verdadeira saída do liberalismo laissez-faire ${ }^{27}$.

Essas ideias expressavam perfeitamente os sentimentos de uma geração de economistas que haviam sido criados em um ambiente intelectual completamente estatista, mas que ainda conheciam os ensinamentos dos liberais clássicos. F. A. Hayek, Wilhelm Röpke, Fritz Machlup, Milton Friedman (1912-2006), Michael Polanyi (1891-1976), Walter Eucken (1891-1950) e muitos outros receberam formação universitária e os impulsos intelectuais decisivos durante os anos 1920 e início dos anos 1930. Durante a década de 1930, começaram a ocupar posições mais altas e, após a guerra, assumiram a liderança intelectual da direita $^{28}$. Seu neoliberalismo animava o traba-

${ }^{27}$ SIMONS, Henry Calvert. A Positive Program for Laissez-Faire: Some Proposals for a Liberal Economic Policy. Chicago: University of Chicago Press, 1934. (Public Policy Pamphlet, No. 15).

${ }^{28}$ Alguns dentre eles, notavelmente Hayek, mais tarde se voltaram para um posicionamento de mais laissezfaire. No entanto, esta volta foi em um momento 
lho das instituições do pós-guerra que conteriam a maré do estatismo crescente, em particular a Mont Pèlerin Society e o Institute of Economic Affairs (IEA) em Londres. Nos anos mais recentes, a agenda neoliberal é levada adiante por uma nova onda de instituições educacionais, como o Institute for Humane Studies (IHS), o Cato Institute e a Atlas Economic Research Foundation. Esses indivíduos e instituições moldaram as políticas neoliberais no mundo ocidental desde o final da Segunda Guerra Mundial.

\section{VI - O colóquio Walter LippmanN}

Sete semanas depois do casamento, Ludwig von Mises participou de um encontro histórico dos paladinos do "velho" liberalismo de Manchester e do neoliberalismo. Margit von Mises (1890-1933) provavelmente o perdoou e até se juntou a ele na viagem. Não é de admirar, pois a conferência ocorreu em Paris.

O neoliberalismo era, no início, um fenômeno puramente informal. Praticamente todos os proponentes eram economistas que cooperavam em uma rede espontânea dentro de algumas instituições como a International Chamber of Commerce (ICC) em Paris. Em meados da década de 1930, a rede atingiu a massa crítica necessária para uma organização mais formal sob a bandeira da nova terceira via. Um passo importante para a aparência organizada da rede neoliberal emergente foi dado quando, em 1937, o jornalista norte-americano Walter Lippmann publicou um manifesto neoliberal com o título Inquiry into the Principles of the Good Society ${ }^{29}$ [Investigação sobre os princípios da boa sociedade].

quando o rolo compressor neoliberal já estava bem encaminhado.

${ }^{29}$ LIPPMANN, Walter. Inquiry into the Principles of the Good Society. Boston: Little, Brown \& Co., 1937.
O livro atraiu os neoliberais europeus, porque Lippmann expressou de maneira eloquente as próprias opiniões sobre as raízes da atual crise política e econômica. Aqueles que ainda se chamavam liberais rejeitavam o socialismo, mas não queriam ser fortemente associados à doutrina do laissez-faire de Manchester. Lippmann se colocou em oposição tanto aos antigos liberais como aos agitadores socialistas contemporâneos. A posição intermediária de Lippmann correspondia à mentalidade pragmática de seus compatriotas. Os norte-americanos tendem a adotar uma abordagem empresarial dos conflitos políticos, buscando resolvê-los por meio de negociações e compromissos. Lippmann apresentou de maneira perspicaz tanto os socialistas quanto os manchesterianos como teimosos doutrinários. Contrastava esses "extremistas" com o próprio esquema prático. Isso repercutiu nos economistas europeus neoliberais continentais do período Entre Guerras, que diferiam de Lippmann apenas nos detalhes vislumbrados para a boa sociedade.

Um desses foi Louis Rougier (1889-1982), filósofo da Universidade de Paris e diretor de um “Centre Danubien”. Rougier considerou o livro de Lippmann uma brilhante exposição de um consenso surgido entre os estudiosos liberais no passado recente, de modo mais notável nos livros de Ludwig von Mises, Lionel Robbins, Bernard Lavergne (1884-1975), Louis Marlio (1878-1952) e Jacques Rueff (18961978) $)^{30}$. Rapidamente, Lippmann arranjou uma edição francesa de seu livro, intutulado La cité libre $^{31}$ [A Cidade Livre], e aproveitou a ocasião para convocar um colóquio de cinco dias em Paris "para rever o processo do capitalismo e tentar definir a doutrina, as condições necessárias para sua implementação e as novas responsabilidades de um verdadeiro liberalismo" ${ }^{\prime 32}$.

${ }^{30}$ ROUGIER, Louis. "Préface". In: Le Colloque Walter Lippmann. Paris: Librairie de Médicis, 1938.

${ }^{31}$ LIPPMANN, Walter. La cité libre. Paris: Librairie de Médicis, 1938.

32 ROUGIER. "Préface". Op. cit. Posteriormente, o mesmo autor enfatizou que o propósito era 
O evento aconteceu em 26 a 30 de agosto de 1938 no Commission Internationale de Coopération Intellectuelle (CICI) [Instituto Internacional de Cooperação Intelectual] e reuniu representantes de liberalismos muito diferentes. Esses homens recaíram em pelo menos quatro grupos, com visões distintamente diferentes sobre a história, a teoria e a agenda política do liberalismo moderno.

O primeiro grupo, que representava a corrente dominante do neoliberalismo, promovia não apenas um compromisso prático, mas também teórico, com o socialismo coercitivo. Estavam dispostos a se comprometer sobre qualquer item em particular para tornar a agenda geral mais palatável para o eleitor. Sua posição pode ser considerada como socialdemocracia "pró mercado".

Em segundo lugar, houve um pequeno grupo de homens, como F. A. Hayek, que estavam insatisfeitos com vários aspectos do liberalismo clássico e endossaram um âmbito de certo modo um pouco maior para a intervenção do governo. Em contraste com o primeiro grupo, porém, sua preocupação fundamental era com a liberdade individual e, com o tempo, assumiram uma postura cada vez mais radical, aproximando-se cada vez mais da posição liberal clássica.

Terceiro, havia um grupo igualmente pequeno de homens, como Alexander Rüstow (1885-1963), relutantes em endossar completamente o liberalismo clássico, porém a principal objeção era contra o igualitarismo, tal como era, dos defensores. Argumentavam que a hierarquia era absolutamente necessária para a manutenção de uma sociedade livre, porque somente a autoridade nela implícita transmitiria com eficácia a tradição cultural da liberdade. O grande erro da Revolução Francesa foi que não só aboliu a hierarquia coercitiva do Ancien Régime, como também desprezou o princípio da hierarquia per se. Em seu fervor igualitário, jogara fora o bebê

definir o neoliberalismo. Ver: ROUGIER, Louis. "Le néolibéralisme". Synthèses (Décembre 1958). da hierarquia natural com a água do banho da hierarquia coercitiva.

Em quarto lugar, e por último, Ludwig von Mises manteve as políticas do laissez-faire do século XIX sobre bases teóricas refinadas que ele mesmo desenvolvera ao longo dos últimos dezoito anos. Na década de 1930, o economista austríaco foi reconhecido dentro e fora dos círculos libertários como o mais importante representante contemporâneo da Escola de Manchester ${ }^{33}$.

O colóquio de Lippmann mostrou que três das percepções de Mises exerceram impacto profundo sobre os neoliberais. Em primeiro lugar, sua demonstração de que o cálculo econômico socialista era impossível os liberou de todas as noções de que uma comunidade socialista plena seria viável ou mesmo desejável por razões econômicas. Em segundo lugar, o argumento do cálculo socialista os convenceu de que a fixação de preços competitivos é da maior importância e uma característica definidora do mercado livre. Terceiro, endossaram a defesa original de Mises do

${ }^{33}$ Ver o seguinte trabalho de um autor esquerdista: HEIMANN, Eduard. History of Economic Doctrines: An Introduction to Economic Theory. New York: New York University Press, 1945. p. 19. O parecerista anônimo da edição francesa do Gemeinwirtschaft apresentou o autor como "o líder incontestável da Escola da Economia Austríaca" (resenha de Le socialisme em Les industries mécaniques. Paris: junho de 1938). Quando Louis Baudin (1887-1964) convidou Mises a juntar-se à comissão científica de um novo periódico francês de economia comparativa, em 1939, disse a ele que todas as orientações políticas seriam representadas na comissão, razão suficiente para que o liberalismo fosse defendido por mestres tais como Mises (ver: Carta Baudin para Mises, datada de 18 de maio de 1939. Grove City Archive, arquivo Baudin). A singularidade do papel de Mises ainda foi reconhecida uns vinte anos mais tarde por um dos últimos estudantes sobreviventes da escola francesa do laissez-faire. Escrevendo para Mises em setembro de 1957, o professor A. Bastet disse que o economista austríaco era o sucessor "do nosso mestre Yves Guyot (1843-1928)" - que fora, por sinal, herdeiro intelectual de Gustave de Molinari, e este um legatário do grande "proto-austríaco" Frédéric Bastiat. Ver: Carta de Bastet para Mises, datada de 5 de setembro de 1957. Grove City Archive, arquivo "B". 
liberalismo, que enfatizava que uma ordem de propriedade privada seria o único sistema viável para a divisão do trabalho.

As duas últimas percepções, no entanto, foram distorcidas, de modo a acomodar a agenda intervencionista neoliberal. Enquanto Mises simplesmente declarara que uma divisão do trabalho baseada no cálculo só poderia ocorrer na presença da propriedade privada, os neoliberais se propuseram a manipular os sistemas jurídico e judicial para "melhorar" a divisão espontânea do trabalho que teria resultado do laissez-faire político. Para esses homens, o mercado era extremamente importante, mas acreditavam que a intervenção do governo poderia melhorar a "eficiência" e "justiça" no processo de mercado. Ao contrário dos socialistas, os neoliberais acreditavam que o mercado conduzia a sociedade na direção correta, mas, ao contrário dos liberais clássicos, acreditavam que o mercado sem entraves estava aquém do seu verdadeiro potencial.

Em um prefácio à primeira edição alemã do livro de Walter Lippmann, lançada em 1945, Wilhelm Röpke enfatizou a orientação das políticas neoliberais para a otimização da máquina social:

Assim, a questão não é: a favor ou contra o laissez-faire? Em vez disso, qual é a ordem jurídica (Rechtsordnung) que se enquadra numa constituição econômica justa, livre, da mais alta produtividade e baseada numa sofisticada divisão do trabalho ${ }^{34}$

Como consequência dessa interpretação particular da teoria de Ludwig von Mises sobre os sistemas sociais, os neoliberais também reinterpretaram o significado das percepções do economista austríaco sobre a importância dos preços competitivos. Mises argumentou

\footnotetext{
${ }^{34}$ RÖPKE, Wilhelm. "Einführung". In: LIPPMANN Walter. Die Gesellschaft freier Menschen. Bern: Francke. 1945. p. 32. Conforme demonstra esse texto, Röpke ficou profundamente impressionado com o trabalho de Lippmann, quem acreditava ter exercido um impacto tremendo sobre o movimento neoliberal.
}

que uma divisão racional do trabalho poderia se basear apenas nos preços de mercado para os fatores de produção, o que, por sua vez, exigia a propriedade privada desses fatores. Em contrapartida, os neoliberais se concentraram exclusivamente nos próprios preços, negligenciando as condições sob as quais ocorrem os preços livres. Para eles, a conclusão prática do argumento do cálculo socialista não era o da não interferência do governo na propriedade em geral, mas sim que deveria evitar de se intrometer especificamente nos preços. No colóquio, Lippmann foi elogiado por sua distinção entre "intervenções compatíveis com o mercado" e intervenções incompatíveis com o funcionamento de uma economia de mercado ${ }^{35}$. Apenas a interferência direta no funcionamento do mecanismo de preços seria ilegítima. Se o governo se limitasse a controlar apenas o marco jurídico no qual os participantes no mercado ficariam livres para prosseguir com seus projetos à vontade, esta intervenção não seria condenável de um ponto de vista neoliberal.

O princípio unificador das teorias neoliberais do pós-guerra foi uma tentativa de justificar a liberdade em alguns casos e a violência patrocinada pelo Estado em outros, por intermédio de uma mesma teoria. Os produtos mais importantes desses esforços foram a teoria dos bens públicos e a teoria de Chicago para o Direito e a Economia de Ronald Coase (1910-2013).

Mises criticou de maneira implacável a interpretação neoliberal do significado do argumento do cálculo socialista. Do seu ponto de vista, a distinção arbitrária entre o "papel do mecanismo de preços" e o "arcabouço do mercado" era absurda. É da natureza da intervenção governamental violar os direitos de propriedade privada, afetando assim o meca-

\footnotetext{
${ }^{35}$ Rüstow se orgulhava de ter cunhado a frase "liberaler Interventionismus" (intervencionismo liberal clássico) já em 1932. Ver a cópia de sua carta para Volkmar Muthesius (1900-1979), datada do dia 23 de maio de 1955. Grove City Archive: Arquivo Muthesius. Provavelmente se referiu ao seu discurso no encontro de 1932 do Verein em Dresden, na Alemanha.
} 
nismo de preços em todos os casos. Embora seja verdade que certos fenômenos resultam apenas de uma interferência direta no processo de fixação dos preços - a escassez e os excedentes, sobretudo -, a grande questão do cálculo econômico permanece. Em última análise, é irrelevante se a intervenção do governo se intromete diretamente com os preços ou indiretamente pela da "estrutura" de formação de preços; em ambos os casos, os preços de mercado são pervertidos.

\section{VII - Leonard ReAd e a Foundation FOR ECONOMIC EducATION (FEE)}

Aproximadamente um ano após o início das palestras de Ludwig von Mises na New York University (NYU), foi criada outra instituição que se mostraria um pilar do renascimento do liberalismo clássico e que daria mais força às ideias do economista austríaco. Leonard Read chegara à conclusão de que seu engajamento com a diretoria da National Industrial Conference Board (NICB) [Conselho da Conferência Nacional das Indústrias] era um desperdício de tempo e de dinheiro. Uma das principais razões para essa ineficácia era o comprometimento da diretoria com uma política de "ouvir os dois lados". Na prática, isso significava, por exemplo, que nas conferências públicas bimestrais que a instituição patrocinava no hotel Waldorf-Astoria, os defensores do livre-mercado e os defensores da intervenção do governo recebiam tempos iguais para apresentar os argumentos. Read acreditou que essa política estava baseada em um mal-entendido severo a respeito do que "ouvir ambos os lados", verdadeiramente, significaria no contexto atual. Nas palavras de sua biógrafa Mary Sennholz:

O "outro lado" estava em toda parte - no governo, na educação e na imprensa. Mesmo os empresários passaram a confiar no governo para restrições de concorrência, para contratos e ordens públicas, assim como dinheiro e crédito fáceis, além de ou- tros favores. [...] Como você apresenta "ambos os lados" quando "um lado" está ao seu redor, antecipando a discussão pública, e o "outro lado" é apenas audível no ruído ensurdecedor do outro? ${ }^{36}$.

Direcionar mais fundos para apresentar a opinião estatista era dinheiro escoando pelo ralo e sentiu que não poderia, em boa consciência, justificar essa despesa. No final de 1945 , renunciou o posto que detinha e começou a visitar os doadores para pedir desculpas $^{37}$. Um deles, o empresário Pierre F. Goodrich (1894-1973), de Nova York, incentivou Leonard Read a pensar na criação de sua própria organização. Dois meses depois, Read estabeleceu a Foundation for Economic Education (FEE), que, em julho de 1946, iria para as instalações bucólicas em Irvington-on-Hudson, várias milhas ao norte de Manhattan, onde ainda está localizada ${ }^{38}$.

${ }^{36}$ SENNHOLZ, Mary. Leonard E. Read: Philosopher of Freedom. Irvington-on-Hudson: Foundation for Economic Education, 1993. p. 69.

${ }^{37}$ Ludwig von Mises continuou sendo convidado para outras conferências da NICB. Por exemplo, no dia 16 de maio de 1946, discutiu o tema das taxas de juros do Pós Guerra com Woodlief Thomas (1897-1974), um economista do Federal Reserve [Reserva Federal], Friedrich Lutz (1901-1975), um representante do ordoliberalismo, e o neokeynesiano Paul Samuelson (1915-2009). E, no dia 22 de janeiro de 1948, participou de um simpósio que lidou com a questão: "Devemos retornar ao padrão-ouro?", no qual debateu com Philip Cortney (1895-1972), L. Albert Hahn (1889-1968) e Michael A. Heilperin (1909-1971). Ver: Grove City Archive: Arquivos NICB. Provavelmente, também, aceitar tais convites foi instrumental para proporcionar ao seu amigo Walter Sulzbach (1889-1969) um emprego no NICB em 1946 ou 1947. Ver: Grove City Archive: Arquivo Sulzbach.

${ }^{38}$ A ampla e bela mansão, na cidade de Irvingtonon-Hudson, no estado de Nova York, que durante sessenta e oito anos abrigou a Foundation for Economic Education (FEE) foi vendida em 2014, por conta tanto dos impostos elevados quanto da excessiva regulamentação estatal. Mesmo diante dos esforços de diferentes gestões da FEE, as inúmeras exigências governamentais para a utilização da casa para realizar cursos e hospedar pesquisadores estavam há quase 
Read mobilizou apoio empresarial importante para esse empreendimento. Possuía uma caderneta repleta de endereços e estava pessoalmente familiarizado com muitos executivos e proprietários de grandes corporações, alguns dos quais também se juntaram à FEE como administradores.

A principal atividade da FEE era emitir panfletos e cartas explicando as "teses da liberdade" para aproximadamente 30.000 famílias $^{39}$. O próprio Read proferiu um grande número de palestras públicas e, juntamente com seu outro grupo de pessoas, logo começaria a oferecer seminários de fim de semana e outros programas educacionais. Os panfletos e conferências colocaram estudantes de todo o país em contato com os escritos de Mises e outras luminárias do liberalismo clássico. Mises foi um dos primeiros economistas contratados para palestras e seminários nas instalações da FEE, e permaneceria como seu centro intelectual por mais de duas décadas ${ }^{40}$.

Seria difícil exagerar a importância do aparecimento de FEE. Embora suas atividades não fossem notadas por um público nacional maior, a própria existência dessa organização deu às forças liberais clássicas, que se encontravam dispersas, foco e orientação. Dera-lhes o que não tinham desde o auge do liberalismo do século XIX: um lar. A FEE forneceu o material e a infraestrutura para um retorno entusiasmado aos ideais dos liberais do laissez-faire do século XIX. Para a pergunta-chave sobre as funções apropriadas do governo, a respos-

uma década impedindo a realização de diversas atividades na sede da instituição. Atualmente a sede da FEE se encontra em um conjunto de salas em um edifício comercial na cidade de Atlanta, na Georgia. (N. E.)

${ }^{39} \mathrm{O}$ número de 30.000 foi atingido no início de 1949 . Ver o memorando de Read datado de 23 de março de 1949. Grove City Archive: Arquivos FEE.

${ }^{40}$ Ele recebia "uma quantia uniforme em intervalos regulares" e assim se tornou, por razões técnicas (leis tributárias), empregado do FEE em outubro de 1946. Ver: Carta de Curtiss para Mises, datada de 8 de outubro de 1946. Grove City Archive: Arquivos FEE. ta manchesteriana da FEE era que o governo deveria ser estritamente limitado à prevenção da "força agressiva" ou violência física ${ }^{41}$.

Mais importante ainda, atraiu jovens interessados na defesa intelectual da liberdade e, em última análise, colocou Mises em contato com um grupo autosselecionado de estudantes, que eram muito mais receptivos às consequências políticas de suas ideias do que muitos dos participantes do seminário na NYU. Vários alunos que conheceu pela primeira vez em conferências da FEE mais tarde se juntaram ao seminário semanal na universidade, onde Mises poderia entrar em muito mais detalhes.

Por último, mas não menos importante, a FEE forneceu algum contrapeso intelectual à ortodoxia neoliberal que estava prestes a surgir no departamento de economia da University of Chicago. Em 1947 e 1948, respectivamente, Frank H. Knight (1885-1972) e o já citado Henry Calvert Simons (postumamente), publicaram coleções de artigos defendendo um libertarianismo tão ralo que não se distinguia da social-democracia ${ }^{42}$. Outros membros da Escola de Chicago foram Aaron Director (1901-2004) e Milton Friedman. O impacto da FEE era, é claro, comparativamente menor, contudo, sem ele, a Escola de Chicago teria dominado totalmente o cenário do livre-mercado norte-americano.

\section{VIII - Frederick Nymeyer}

Mais ou menos na mesma época em que Leonard Read estava criando a FEE em Irvington-on-Hudson, no estado de Nova York,

\footnotetext{
${ }^{41} \mathrm{NASH}$. The Conservative Intellectual Movement in America. Op. cit., p. 24.

${ }^{42}$ KNIGHT, Frank H. Freedom and Reform. New York: Harper, 1947; SIMONS, Henry Calvert. Economic Policy for a Free Society. Chicago: University of Chicago Press, 1948.
} 
Ludwig von Mises travou conhecimento com outra pessoa que por fim se transformaria em um aliado de longo prazo. Em maio de 1946, o empresário de Chicago, Frederick Nymeyer, terminou de ler a Theorie des Geldes und der Umlaufsmittel ${ }^{43}$ [A Teoria da Moeda e dos Meios Fiduciários], o que o levou a escrever ao autor e a perguntar a respeito de outros escritos sobre o assunto ${ }^{44}$. Durante os meses seguintes, Nymeyer leu Omnipotent Government $^{45}$ [Governo Onipotente] e outros escritos em inglês do professor austríaco que estavam disponíveis. Era o leitor ideal para Mises. Recebera educação econômica no início da década de 1920, depois trabalhara por algum tempo como representante de campo do Harvard Business Cycle Index. Estava bem familiarizado com o pensamento monetário que prevaleceu nos Estados Unidos. O livro Theorie des Geldes und der Umlaufsmittel, conforme descobriu, "era radicalmente diferente da abordagem mecanicista Teoria Quantitativa da Moeda" e, portanto, "tive alguma dificuldade para ajustar todo o meu pensamento à sua exposição". Parte da dificuldade parecia ser o uso diferente de termos, e Nymeyer, em seguida, passou a levantar questões sobre um dos conceitos cruciais da teoria: a demanda por moeda ${ }^{46}$. Mises concordou que a maneira como a expôs - a demanda por moeda como demanda por poder de compra - era ambígua, e que uma

${ }^{43}$ Livro publicado originalmente em alemão no ano de 1912, cuja segunda edição neste mesmo idioma, de 1924, serviu como base para uma versão inglesa, lançada em 1934, e disponível, atualmente, na seguinte edição: MISES, Ludwig von. Theory of Money and Credit. Pref. Murray N. Rothbard; intr. Lionel Robbins; trad. Harold E. Batson. Indianapolis: Liberty Fund, 1981. (N. E.)

${ }^{44}$ Carta de Nymeyer para Mises, datada de 20 de maio de 1946. Grove City Archive: Arquivos Nymeyer.

${ }^{45}$ A obra publicada originalmente em inglês, em 1944, está disponível atualmente na seguinte edição: MISES, Ludwig von. Omnipotent Government: The Rise of the Total State and Total War. Ed. e pref. Bettina Bien Greaves. Indianapolis: Liberty Fund, 2011. (N. E.)

${ }^{46}$ Carta de Nymeyer para Mises, datada de 12 de junho de 1947. Grove City Archive: arquivos Nymeyer. maneira melhor de dizer isso era que os participantes do mercado demandavam a retenção de dinheiro. Prometeu rever seus escritos de modo adequado e considerar esse ponto em seu próximo tratado sobre Economia.

Essa troca foi o início de uma aliança duradoura (embora nunca uma amizade mais pessoal). Nymeyer logo começou a ler outras obras de economistas austríacos disponíveis em inglês, em particular Kapital und Kapitalzins $^{47}$ [Capital e Juros] de Eugen von Böhm-Bawerk (1851-1914). Lentamente, tornou-se um admirador dedicado da Escola Austríaca. Também era um calvinista devoto e afirmou: "Böhm-Bawerk foi demasiado longe, além de Adam Smith, como João Calvino (1509-1564) foi além de Martinho Lutero (1483-1546)"48.

$\mathrm{O}$ agnosticismo de Ludwig von Mises não diminuiu a admiração de Frederick Nymeyer pelo economista austríaco. E não impediu o próprio Mises de cooperar aberta e produtivamente com os libertários cristãos nos Estados Unidos. Na Áustria, tal cooperação era praticamente impossível, porque os socialistas cristãos haviam empurrado a Igreja Católica para um beco intelectual sem saída. Somente personalidades destacadas como o monsenhor Ignaz Seipel (1876-1932) poderiam superar os ressentimentos socialistas contra o liberal Mises. Entretanto, nos Estados Unidos as coisas eram diferentes. Muitos

${ }^{47}$ A obra em três volumes lançada originalmente em alemão entre 1884 e 1914 foi publicada em língua inglesa na seguinte edição: BÖHM-BAWERK, Eugen von. Capital and Interest. Trad. George D. Huncke e Hans F. Sennholz. South Holland: Libertarian Press, 1959. 3v. [Volume I: History and Critique of Interest Theories / Volume II: Positive Theory of Capital / Volume III: Further Essays on Capital and Interest]. Em língua portuguesa o capítulo XII do primeiro volume foi publicado como o seguinte livro: BÖHM-BAWERK, Eugen von. A Teoria da Exploração do Socialismo Comunismo. Pref. Hans F. Sennholz; trad. Lya Luft. São Paulo: Instituto Ludwig von Mises Brasil, 2 ${ }^{\underline{a}}$ ed., 2010. (N. E.)

${ }^{48}$ Carta de Nymeyer para Mortimer Adler, datada de 14 de fevereiro de 1948. Grove City Archive: Arquivos Nymeyer. 
clérigos protestantes no país amavam a liberdade individual e o livre-mercado, e consideravam que esse amor resultava naturalmente de sua religião cristã. Muitos desses homens achavam que as teorias de Mises eram complementares à sua fé.

Em correspondência com um clérigo da Igreja Anglicana, no Canadá, que havia lido o livro Human Action: A Treatise on Economics ${ }^{49}$ [Ação Humana: Um Tratado de Economia], Mises escreveu:

Concordo plenamente com sua afirmação de que os Evangelhos não defendem políticas anticapitalistas. Lidei com esse problema há anos em meu livro Socialismo [...]. Além disso, concordo inteiramente com sua proposição de que não se encontra, em $A c ̧ a \tilde{o}$ Humana "uma só palavra que esteja em oposição à fé cristã" ${ }^{50}$.

Mises acolheu com entusiasmo a publicação do periódico mensal Faith and Freedom da Spiritual Mobilization, uma organização baseada em Los Angeles, em dezembro de 1949. Claro que sabia muito bem que a maioria dos líderes protestantes defendia alguma forma de socialismo ou intervencionismo, e que embora a Igreja Católica "lute valentemente contra o comunismo", não se opõe ao socialismo. Mas esses problemas estavam fora de seu campo: "Creio que só os teólogos são capacitados para lidar com a questão".

Essa também foi a opinião de Frederick Nymeyer. Um dos principais motivos do estímulo para divulgar os escritos de Ludwig von Mises foi precisamente a relação complementar que percebeu entre o capitalismo do laissez-faire e o cristianismo.

\footnotetext{
${ }^{49} \mathrm{O}$ livro está disponível em português na seguinte edição: MISES, Ludwig von. Ação Humana: Um Tratado de Economia. Trad. Donald Stewart Jr. São Paulo: Instituto Ludwig von Mises Brasil, 3르 Ed., 2010. (N. E.)

${ }^{50}$ Carta de Mises para P. C. Armstrong, datada de 16 de janeiro de 1950. Grove City Archive: Arquivo Armstrong.
}

Mises e Nymeyer provavelmente se encontraram pela primeira vez no final de janeiro de 1948. Nymeyer começou, então, a pensar sobre por que a Escola Austríaca de Economia não era preponderante nos Estados Unidos e chegou à conclusão de que obras austríacas não eram suficientemente conhecidas. No outono daquele ano, estava pronto para agir, contando especialmente com a volumosa caderneta de endereços ("conheço vários dos grandes empresários do país, onde participo de alguns importantes conselhos de administração" ${ }^{15}$ ). E, no final de janeiro de 1949, depois de mais alguns encontros com Mises, Nymeyer desenvolveu um plano: a ideia era criar um "Instituto Liberal" sob a liderança de Mises na Chicago University - Nymeyer era amigo do reitor da Escola de Negócios - ou de alguma outra universidade adequada na área de Chicago ${ }^{52}$. Nymeyer já havia conquistado seu sócio Robert W. Baird (1883-1969) e o amigo John T. Brown (1876-1951), vice-presidente da J. I. Case Company. Em maio de 1949, conversaram com vários outros empresários da região.

No final de abril, a universidade dissera a Nymeyer que prefeririam "presentes irrestritos" para serem usados com "liberdade acadêmica" - o que significava que a instituição selecionaria a equipe do Instituto Liberal proposto. Mises comentou:

Com base nesse slogan ["liberdade acadêmica"], as universidades estão boicotando todos os economistas que se atrevem a levantar objeções contra o intervencionismo de outro ponto de vista que não seja o do socialismo. Atualmente, a questão da liberdade acadêmica não é se os professores comunistas devem ser tolerados. Melhor: só devem ser nomeados comunistas, socialistas ou intervencionistas? ${ }^{53}$

${ }^{51}$ Carta de Nymeyer para Mises, datada de 12 de outubro de 1948. Grove City Archive: Arquivos Nymeyer.

${ }^{52}$ Carta de Nymeyer para Mises, datada de 25 de janeiro de 1949. Grove City Archive: Arquivos Nymeyer.

${ }^{53}$ Manuscrito de uma carta de Mises para Nymeyer, em resposta à carta de Nymeyer datada de 26 de abril de 1949. Grove City Archive: Arquivos Nymeyer. 
Entretanto, a resistência não veio apenas do interior das universidades. Alguns anos mais tarde (e muito mais sábio), Mises reconheceu a existência de outro fator:

Uma das piores características do atual estado de coisas é a lealdade equivocada dos ex-alunos. Assim que alguém se atreve a criticar algo relativo a uma universidade, todos os ex-alunos vêm em socorro de sua alma mater. Então, temos o espetáculo das grandes empresas defendendo o boicote lançado pelas faculdades contra todos aqueles que não simpatizam com o intervencionismo, o planejamento e o socialismo ${ }^{54}$.

Em todo caso, o plano para um "Instituto Liberal" baseado em Chicago sob a liderança de Mises não se materializou. Mas Nymeyer e seus amigos tiveram provavelmente alguma influência ao levar F. A. Hayek para a Chicago University, além de desempenharem no início dos anos 1950 um papel significativo para levantar fundos para as reuniões da Mont Pèlerin Society ${ }^{55}$.

\section{IX - Uma CONFERÊNCIA EM Mont PÈLERIN}

Exatamente um ano após a fundação da Foundation for Economic Education (FEE) em Nova York, outra organização foi criada para suprir um fórum para a mudança e o desenvolvimento de ideias relevantes a partir de uma perspectiva liberal clássica. Ao contrário da FEE, essa organização não tinha sede permanente; foi concebida como uma sociedade de acadêmicos, e a vida dessa sociedade consistia principalmente em reuniões anuais, que ocorreram em diferentes cidades por todo o mundo. Mais importante ainda, porém, essa

\footnotetext{
${ }^{54}$ Carta de Mises para Nymeyer, datada de 17 de maio de 1952. Grove City Archive: arquivos Nymeyer.

${ }^{55}$ Nymeyer para Hayek e outros, correspondência da primavera e verão de 1952. Grove City Archive: Arquivos Nymeyer.
}

sociedade foi fundada no espírito do neoliberalismo; e os acadêmicos, políticos e jornalistas neoliberais representam, desde então, a maior parte dos membros.

A sociedade deu prosseguimento ao colóquio de Walter Lippmann de 1938 que Louis Rougier (1889-1982) organizou em Paris. Desta vez, a iniciativa recaiu naturalmente nas mãos de F. A. Hayek, bem conhecido em ambos os lados do Atlântico - devido ao sucesso do livro The Road to Serfdom ${ }^{56}$ [O Caminho da Servidão], de 1944, e, também, porque estava entre os primeiros intelectuais ocidentais a renovar os contatos com os homólogos continentais depois da Segunda Guerra Mundial ${ }^{57}$. Nessas reuniões, surgiu lentamente a ideia de uma associação libertária. Hayek certamente discutiu o assunto quando encontrou Mises no fim de julho de 1946 no México, mas nesse ponto ainda não se transformara em nenhum plano concreto. Da Cidade do México, voou para Oslo, na Noruega, onde Trygve Hoff (1895-1982) organizou uma reunião preparatória para discutir o plano, um pouco vago, para o estabelecimento de uma associação neoliberal com vários intelectuais europeus, e foi ali que o plano de uma "Sociedade Acton-

${ }^{56}$ Acrescida de um longo estudo introdutório e de diversos anexos escritos por renomados economistas, foi publicada em inglês a seguinte edição crítica: HAYEK, F. A. The Road to Serfdom: Text and Documents - The Definitive Edition. Ed. e introd. Bruce Caldwell. Chicago: Chicago University Press, 2007. Traduzida com base na versão inglesa de 1976, a obra está disponível em português na seguinte edição: HAYEK, F. A. O Caminho da Servidão. Trad. Ana Maria Copovilla, José Ítalo Stelle e Liane de Morais Ribeiro. São Paulo: Instituto Ludwig von Mises Brasil, 6 ${ }^{\underline{a}}$ ed., 2010. (N. E.)

${ }^{57}$ Por exemplo, por volta de janeiro de 1949, Hayek já havia realizado diversas visitas à Áustria. Ver carta de Charmatz para Mises, datada de 27 de janeiro de 1949. Grover City Archive: Arquivo Charmatz. 
-Tocqueville" ${ }^{\prime 58}$ deve ter tomado forma ${ }^{59}$. Até o final do ano, encontrara os fundos necessários para patrocinar o evento com fontes suíças, por intermédio de Albert Hunold (18991980), e norte-americanas, via William Volker Fund ${ }^{60}$, bem como escreveu uma carta circular

${ }^{58} \mathrm{O}$ nome originalmente escolhido por F. A. Hayek era em homenagem ao estadista, pensador político e historiador católico francês Alexis de Tocqueville (18051859) e ao ao historiador, editor, jornalista e estadista católico inglês John Emerich Edward Dalberg-Acton (1834-1902), mais conhecido como Lorde Acton. (N. E.)

${ }^{59}$ Ver carta de Hayek para Mises, circular datada de 28 de dezembro de 1946. Grove City Archives: Arquivos da Mont Pèrelin Society (MPS). Ver, também: Carta de Mises para Karl Brandt, datada de 7 de setembro de 1946. Grove City Archives: Arquivo Brandt. Mises esteve em contato com Hoff antes do dia 28 de junho de 1946. Hoff escreveu um manifesto libertário durante a guerra e enviou o texto para a Suécia, de onde um diplomata norte-americano deveria tê-lo enviado para o editor Alfred Knopf (1892-1984) em Nova York. Mas o diplomata nunca o fez, como Hoff veio a saber depois da guerra, porque considerou o manuscrito "não democrático" - o que provavelmente significou que era muito crítico dos dogmas fundamentais do aliado de guerra dos Estados Unidos. Hoff também veio a descobrir, de maneira independente, a impossibilidade do cálculo econômico no socialismo. Mises tinha o economista norueguês em alta consideração. Hoff foi "um dos poucos contemporâneos cujo julgamento a respeito dos problemas tratados em Ação Humana é consequente". Carta de Mises para Hoff, datada de 11 de janeiro de 1950. Grove City Archives: Arquivos Hoff.

${ }^{60}$ Criada no ano de 1932, em Kansas City, no estado de Missouri, pelo empresário William Volker (18591947), essa fundação de caridade originalmente tinha como principal missão ajudar na reforma dos sistemas educacional e de saúde na cidade onde estava sediada, além defender menor interferência das esferas federal e estadual nas políticas municipais. Sob a gestão de Harold W. Luhnow (1895-1978), sobrinho do fundador, a instituição mudou o foco e passou a financiar autores libertários e conservadores, além de colaborar na criação da Foundation for Economic Education (FEE) em 1946, da Mont Pèlerin Society em 1947 e do Intercollegiate Society of Individualists (ISI) em 1953, tendo a última, por influência de Russell Kirk (1918-1994), mudado o nome, posteriormente, para Intercollegiate Studies Institute (ISI). Em 1961 foi criado o Institute for Humane Studies (IHS), com suporte do William Volker Fund, que acabou, em pouco tempo, assumindo os recursos e a missão dessa fundação de caridade. (N. E.) de convite para cerca de cinquenta pessoas, para uma conferência de dez dias nos Alpes suíços, na parte inferior do Monte Pèlerin, perto da cidade de Vevey, no Lago Genebra.

F. A. Hayek provavelmente antecipou algum problema com Ludwig von Mises, porque pediu desculpas escritas à mão nessa mesma carta, dizendo que não tivera tempo para discutir o plano com Mises em detalhes. Sua apreensão acabou se mostrando acertada. Mises respondeu, escrevendo para Hayek que não poderia deixar a New York University (NYU) em abril e que "abomino a ideia de ir para a Europa. Já vi decadência suficiente" ${ }^{\prime 61}$. A pedido de Henry Hazlitt (1894-1993), havia escrito um memorando de quatro páginas contendo suas "Observations on Professor Hayek's Plan" ["Observações sobre o plano do professor Hayek"]. Neste documento, afirmou que muitos planos semelhantes para conter a maré do totalitarismo tinham sido tentados nas últimas décadas - ele mesmo estava envolvido em alguns desses projetos - mas os planos fracassavam porque esses amigos da liberdade já haviam sido infectados pelo vírus estatista: "Não perceberam que a liberdade se encontra inextricavelmente conectada à economia de mercado. Apoiaram, em geral, a parte crítica do programa socialista. Comprometeram-se como uma solução de terceira via, o intervencionismo". No final do memorando, afirmou sua principal objeção:

O ponto fraco do plano do professor Hayek é que se baseia na cooperação de muitos homens que são conhecidos pelo apoio ao intervencionismo. É necessário esclarecer esse ponto antes do início da conferência. Do modo como entendo o plano, não é tarefa desta conferência discutir novamente se um decreto do governo ou a determinação de um sindicato tem ou não a capacidade de elevar o padrão de vida das massas. Se alguém deseja discutir esses problemas, não é necessário que faça uma peregrinação ao Monte Pèlerin. Poderá encontrar, em sua

${ }^{61}$ Carta de Mises para Hayek. Datada de 31 de dezembro de 1946. Grove City Archives: arquivos MPS. 
própria vizinhança, muitas oportunidades para fazer isso ${ }^{62}$. fico:

Em sua carta a Hayek, foi mais especí-

Estou preocupado sobretudo com a participação de Wilhem Röpke, que é um intervencionista declarado. Creio que o mesmo vale para Karl Brandt (1904-1948), Harry Gideonse (1901-1985) e Max Eastman (18831969). Todos os três contribuem para a New Leader, uma revista puramente socialista embora decididamente antissoviética ${ }^{63}$.

Ainda assim, Mises não descartou sua participação, mas sugeriu um adiamento da conferência até setembro. Isso acabou sendo impraticável, e Hayek empreendeu outra tentativa de convencer o velho mentor no início de fevereiro. Minimizou a importância das conexões de Brandt, Gideonse e Eastman com a New Leader, mencionando que ele próprio já escrevera para essa revista. Contudo, o mais importante foi o argumento de que o programa da conferência ainda era bastante aberto e que o principal objetivo da reunião de Vevey e dos encontros subsequentes seria conquistar especialmente aqueles historiadores e cientistas políticos que ainda abrigavam ideias equivocadas sobre uma série de questões, mas que estavam dispostos a aprender ${ }^{64}$. Isso foi, aparentemente, bastante convincente. Por sugestão de Hayek, Mises entrou em contato com o principal patrocinador da conferência, o já citado William Volker Fund, com sede em Kansas City, no estado de Missouri, e, dentro

\footnotetext{
${ }^{62}$ Memorando datilografado de 31 de dezembro de 1946. Grove City Archive: Arquivos MPS.

${ }^{63}$ Carta de Mises para Hayek, datada de 31 de dezembro de 1946. Grove City Archive: Arquivos MPS. Mises sugeriu que Hayek convidasse Luis Montes de Oca (1894-1958) e Gustavo R. Velasco (1903-1982) do México, Raúl Maestri (1908-1973) de Cuba e Torleiv Hytten (1890-1980) da Austrália.

${ }^{64}$ Carta de Hayek para Mises, datada de 3 de fevereiro de 1947. Grove City Archive: Arquivos MPS.
}

de uma semana, os arranjos de viagem foram feitos por intermédio da FEE.

$$
* * *
$$

A conferência da Mont Pèlerin começou em $1^{0}$ de abril de 1947 e consistiu em dez dias de sessões. Ludwig von Mises saíra de Nova York em 25 de março, animado e curioso para ver a Europa novamente depois de quase sete anos. Provavelmente viajou para a conferência via Paris e Genebra, onde conheceu William Rappard (1883-1958) e o já citado Paul Mantoux ${ }^{65}$. A reunião teve apenas uma agenda mínima e deixou grande margem de manobra para que os participantes determinassem os temas que desejariam discutir nos próximos dias.

Ludwig von Mises e os outros seis nova-iorquinos - Leonard Read, F. A. Harper (1905-1973) e Vernon Orval Watts (1898-1993) da FEE, bem como o jornalista Henry Hazlitt, Harry Gideonse, que na época era presidente do Brooklyn College, e John Davenport (19041987), da Fortune Magazine - representaram a guarnição manchesteriana da reunião. F. A. Hayek, Milton Friedman e Fritz Machlup eram neoliberais; pessoas como Walter Eucken, Bertrand de Jouvenel (1903-1987), Frank H. Knight, Michael Polanyi, Karl Popper (19021994) e George J. Stigler (1911-1991) já eram social-democratas bastante liberais; e Maurice Allais (1911-2010), Wilhelm Röpke e Lionel Robbins representavam a extrema-esquerda da conferência. Allais não foi capaz de endossar a vaga "declaração de objetivos" que todos os outros participantes aprovaram em 8 de abril.

No discurso de abertura, Hayek estabeleceu a agenda para a reconstrução ideológica no Pós Guerra do movimento do liberalismo clássico. Isso sugeria, por um lado, "purgar a teoria liberal tradicional de certos acréscimos aci-

\footnotetext{
${ }^{65}$ Carta de Mises para Montes de Oca, datada de 13 de março de 1947. Grove City Archive: Arquivos Montes de Oca. Carta de Mises para Mantoux, datada de 17 de março de 1947. Grove City Archive: Arquivo Mantoux.
} 
dentais que a ela se uniram no transcurso do tempo" e, por outro lado, "enfrentar alguns problemas reais dos quais o liberalismo supersimplificado se esquivou ou que se tornaram aparentes somentea partir o momento em que se transformou em credo, de certo modo, estacionário e rígido"66. Como os desdobramentos posteriores devem mostrar, o significado concreto desse programa foi: 1) absolver o liberalismo clássico de certas críticas amplamente difundidas, por exemplo, de que as políticas que inspirara haviam levado à miséria das massas; 2) distinguir o liberalismo "moderno" de seu predecessor mais antigo, o laissez-faire.

Algumas das outras palestras programadas, contudo, foram suficientes para justificar as premonições negativas de Ludwig von Mises. Por exemplo, o economista alemão Walter Eucken explicou que a legislação antimonopólio não era suficiente para combater os monopólios. Maior inferência legislativa seria necessária nos campos do direito corporativo, bem como do direito de marcas e patentes. Defendeu, também, duas máximas da política econômica. Em primeiro lugar, embora houvesse liberdade de contrato, esta liberdade não devia se limitar de modo algum à liberdade de contrato para demais. Em segundo lugar, os participantes monopolistas do mercado deveriam ser forçados a se comportar como se estivessem sob "concorrência" - produzir as mesmas quantidades e vendê-las aos mesmos preços que prevaleceriam na "concorrência".

Eucken resumiu a mesma agenda intervencionista que já dominara o colóquio de Lippmann em 1938. Na época, Mises estava em lua-de-mel na cidade de Paris, o que pode explicar por que suas contribuições às dis-

${ }^{66}$ Ver o discurso pronunciado, em $1^{\mathrm{o}}$ de abril de 1947, por F. A. Hayek na abertura da conferência na Mont Pèlerin Society. Ver, também, o texto bastante moderado "Statement of Aims" [Declaração de Objetivos] da Mont Pèlerin Society. Uma cópia do documento original se encontra no Grove City Archive: Arquivo do Intercollegiate Society of Individualists (ISI). Arquivado por volta de 1964. cussões haviam sido excepcionalmente tranquilas. Agora era nove anos mais velho, mas a lua-de-mel tinha terminado. Reagiu com grande determinação e defendeu sua posição pelo laissez-faire tão vigorosamente que, muitos anos depois, seu amigo Lawrence Fertig (1898-1986) ainda recordava o debate.

O intercâmbio entre Ludwig von Mises e os opositores neoliberais estabeleceu o tom na Mont Pèlerin Society nos próximos anos. Embora os libertários em torno de Mises fossem apenas uma pequena minoria, eram os que tinham o apoio financeiro dos principais patrocinadores norte-americanos, como o William Volker Fund, sem o qual a Mont Pèlerin Society teria morrido muito rapidamente naqueles primeiros anos. Desde que Mises tomou parte ativa nas reuniões, portanto, ficou impossível simplesmente discutir os detalhes técnicos do intervencionismo governamental. O laissez-faire havia retornado. Não era a opinião da maioria, mas era uma opção política discutível e debatida - demais para alguns membros iniciais, como Maurice Allais, que logo abandonou a Sociedade precisamente por essa razão ${ }^{67} \cdot \cos$

\footnotetext{
${ }^{67}$ Provavelmente, a visita de Allais à FEE em outubro de 1947 reforçou as preocupações de que os libertários norte-americanos fossem muito radicais para o seu gosto. A visita é mencionada em carta de Herbert Cornuelle para Mises, datada de 14 de outubro de 1947. Grove City College Archive: Arquivos FEE.
} 